\title{
Мотивационно-смысловая основа участия молодежи в добровольческой деятельности
}

Статья посвящена анализуевропейскихисследований мотивачионно-смысловой сферы молодыхлюдей, участвующих в добровольческой деятельности. Приводится авторское исследование мотивачионно-смысловой сферы молодежи, в котором приняли участие представители политических, добровольческих, религиозных молодежных общественных организаций, авторы собственных добровольческих проектов, а также студенты ЮФу, не вовлеченные в деятельность подобного рода - молодые люди в возрасте от 14 до 30 лет, общее число - 160 человек, из них 96 девушек и 64 юноши.

Подводя итоги проведенного анализа результатов диагностики, автор резюмируе, что гипотетическое предположение о возможности выявления смысложизненных стратегий молодежи, различающейся по степени включенности в общественную деятельность, удалось реализовать на практике. Также были сформированы симптомокомплексы по каждому из выделенных типов личности, которые позволяют определить особенности молодежи и впоследствии разработать методы социально-психологической поддержки для каждого из типов организачий.

Ключевые слова: молодежь, социальная активность, волонтеринг, общественно-политические организачии, мотивачионно-смысловая срера.

На сегодняшний день в странах Западной Европы накоплен значительный опыт организации добровольческих движений и распространения волонтеринга в молодежной среде. Являясь значимой составляющей общественной жизни, волонтеринг также представляет собой активно разрабатываемую научную проблему. Так, в Великобритании существует целый институт, занимающийся изучением этого социального явления. Анализ исследований и опыта организации волонтерского движения в Европе может стать важным шагом на пути разработки соответствующей программы социально-психологического сопровождения молодежи в России.

В современном обществе добровольцы очень востребованы, и на них возлагаются большие надежды. Ожидается, что успешное вовлечение молодежи в волонтерскую деятельность улучшит ее социальные навыки, укрепит социальную сплоченность, будет способствовать интеграции «неблагополучной» молодежи, снизит уровень преступности и антисоциального поведения. Предметом исследования Марка Хутина (Mark Hutin), проведенного в Институте исследований добровольчества в 2006-2007 гг., было изучение мотивов, побуждений и результатов деятельности молодых волонтеров Англии.

В ходе исследования было установлено, что $57 \%$ опрошенных молодых людей принимали участие в добровольческой деятельности. При этом наиболее популярным местом работы волонтера были учебные заведения различного уровня, 
а наиболее популярным занятием - организация и проведение праздников. Большинство респондентов указало, что желание улучшить порядок вещей и помочь другим было главным мотивирующим фактором. Почти все опрошенные отозвались позитивно о своем волонтерском опыте [6].

В рамках другого исследования, проведенного в этом же институте, был проведен более глубокий анализ мотивов добровольческой деятельности и оценка влияния волонтерского труда на развитие личности. В ходе исследования было выяснено, что большинство студентов имели опыт работы волонтером до поступления в вуз. Наиболее распространенными мотивами были желание помочь, приобрести новых знакомых, добавить положительную статью к своему резюме. Кроме того, было установлено, что добровольчество непосредственно развивает навыки межличностного общения, необходимые при трудоустройстве: коммуникативные способности, умение работать в команде, социальные навыки. Вместе с тем, у добровольца косвенно развиваются специфические навыки, например, технические, или «потенциал заработка» (K. Donahue, J. Russell) [2].

К схожим выводам пришла и исследовательская группа Национального центра координации и связей с общественностью (National Centre for Public Engagement), изучавшая роль волонтеринга в жизни студентов высших учебных заведений, а также результаты деятельности студенческих добровольческих организаций. Авторы исследования утверждают, что занятия волонтерингом оказывают благотворное влияние, как на самих студентов-добровольцев, так и на широкую общественность. С целью повышения результатов вклад каждого молодого волонтера рекомендуется отмечать и поощрять.

Другим масштабным исследованием студентов-волонтеров была исследовательская работа Клер Холдсворф (Clare Holdsworth) «Студенты-волонтеры в национальном контексте» (Student Volunteers. A national profile), реализованная в рамках двух организаций - «Добровольчество Англии» (Volunteering England) и упоминавшегося ранее Института исследований добровольчества. В исследовании приняли участие студенты всех уровней обучения: от момента поступления в вуз и вплоть до окончания магистратуры. В ходе исследования было установлено, что 15 \% новичков являлись членами благотворительных организаций еще до поступления в вуз. Рейтинг волонтерской активности был самым высоким у студентов медицинских, стоматологических и социальных профессий. Студенты, принадлежащие к этническим меньшинствам, студентыинвалиды и студенты, имеющие обязательства по уходу за кем-то из родных, также продемонстрировали высокий уровень добровольческой активности. Самым низким этот показатель был у обучающихся естественным и техническим наукам, строительству и планированию. Для большинства респондентов главной причиной занятия волонтерингом было желание помочь окружающим. Однако для младших студентов, студентов естественных наук и студентов мужского пола было характерно выделять в качестве основного мотивирующего фактора «новые знакомства» [4]. 
В контексте взаимовлияния высшего образования и добровольческой деятельности было проведено исследование Тайгер де Суза (Tiger de Souza). Им был рассмотрен такой аспект добровольческой деятельности, как спортивный волонтеринг и влияние на него высшего образования. Исследователем было установлено, что привлечение студентов и людей с высшим образованием повышает качество волонтерской деятельности, а для них это часто становится фактором последующего профессионального роста. Автор заканчивает статью размышлением о том, что сегодняшние инвестиции в студенческое спортивное волонтерство смогут позитивно повлиять на новые поколения волонтеров завтра [7].

В работе Катрин Гаскин (Katherine Gaskin) анализируются и обобщаются литературные данные об отношении молодежи к добровольческой работе и их участии в общественной деятельности. Автор отмечает, что в начале 2000-х гг. обстановка с добровольческой активностью в Европе ускоренно менялась. Трудовое законодательство начало пропагандировать волонтерскую деятельность как центр развития демократического общества, что способствовало увеличению числа добровольцев [3].

Между тем в зарубежных исследованиях общественной активности молодежи встречается мнение, что современный мир с его ориентацией на индивидуалистические потребности и конкуренцию неминуемо будет способствовать разрушению волонтеринга как социального явления. Однако Лесли Хустинкс (Lesley Hustinx) опровергает мнение о том, что культурный процесс «индивидуализации» является угрозой добровольческой активности молодежи. На примере изучения бельгийского агентства, организующего международные трудовые лагеря, автор показывает, как добровольчество может помочь молодежи управлять своей свободой и сделать успешный жизненный выбор. Работа в международном трудовом лагере может не только стимулировать личностное развитие (в данном случае через контакт с другими культурами), но и уменьшить неуверенность, которую испытывают молодые люди в своей будущей карьере [5].

Современные молодые волонтеры имеют некоторые черты, которые, казалось бы, не должны быть у добровольца: они не преданы определенной добровольческой организации, избирательны к тому, чем занимаются и ожидают получить личные выгоды. Однако автор считает, что можно продуктивно скомбинировать такое «потребительское» отношение волонтера с искренним чувством единства, отождествлением себя с основными заповедями добровольческой организации и подлинной приверженностью своей работе. Учет интересов и потребностей волонтеров в организации их деятельности поможет обеспечить благоприятное развитие добровольчества, в противовес традиционным способам организации труда.

Приведенные исследования позволяют составить целостную картину волонтеринга как социального явления: определить мотивы и цели участия в данной деятельности, выявить потенциальных волонтеров, наметить основные направления деятельности. Молодежные общественные организации 
являются мощным социальным ресурсом, но для того, чтобы этот ресурс начал функционировать, необходима разработка специализированных программ, которые, в свою очередь, могут быть построены на основании исследования мотивационно-смысловой сферы участников общественных организаций различной направленности.

В 2007-2011 гг. в г. Ростове-на-Дону было предпринято исследование смысложизненных стратегий активного социального поведения молодежи. В проведенном исследовании приняли участие молодые люди в возрасте от 14 до 30 лет, общее число - 160 человек, из них 96 девушек и 64 юноши. Респонденты были условно разделены на две категории: те, которые являются членами общественных организаций, и те, которые ими не являются. При этом обе категории по итогам анкетирования были также поделены на несколько групп. Первая категория, члены общественных организаций, были поделены на три группы по характеру организаций: политические, религиозные и добровольческие. Группа общественно-политических организаций была представлена членами двух организаций, представляющих различные политические блоки: Ростовское региональное отделение Всероссийской общественной организации «Молодая гвардия Единой России» и Союз коммунистической молодежи. Респондентами группы общественно-религиозных организаций стали представители двух христианских конфессий: православные христиане (Молодежный отдел Ростовской Епархии «MOРЕ», сестры милосердия различных приходов г. Ростова-на-Дону) и протестанты (общественно-религиозная организация церкви Евангельских Христиан Баптистов «Подростковый Клуб“Большая Перемена”»). В третью группу вошли волонтеры, не принадлежащие к конкретным организациям и члены общественных организаций неполитического и нерелигиозного характера, в числе которых: «Молодые медики Дона», «Dance for life», «Юные журналисты» и др. Молодые люди, не участвующие в общественных движениях, были отобраны из числа студентов 3-4 курсов Южного федерального университета (факультет психологии, химический и исторический факультеты). Экспериментальной группой стали участники формирующего эксперимента - выпускники проекта «Шаг в психологию» и участники молодежного клуба «Добровольческая служба» Центра по работе с одаренными детьми «Дар» Дворца творчества детей и молодежи г. Ростова-на-Дону.

Диагностика смысловой сферы молодежи различной степени включенности в общественную деятельность была проведена при помощи шести диагностических методик, направленных на выявление направленности личности, оценку мотивационной сферы, смысложизненных и ценностных ориентаций («Мотивация одобрения», «Мотивация достижения», «Мотивация успеха и боязнь неудачи», «Ориентационная (ориентировочная) анкета», «Тест смысложизненных ориентаций» Д. А. Леонтьева и «Ценностные ориентации» М. Рокича). При анализе результатов диагностики были выделены семнадцать шкал. С целью выявления смысложизненных стратегий участников общественных организаций нами был проведен статистический анализ полученных данных по критерию Манна-Уитни. 
Анализ выявленных межгрупповых различий по каждой шкале позволил установить наличие достоверных особенностей смысловой сферы каждой из групп исследования.

По результатам проведенной диагностики были составлены симптомокомплексы личностных особенностей различных групп молодежи, участвующих в общественной деятельности. В основу было положено статистическое определение среднего значения с учетом доверительного интервала.

\section{Доброволеч}

Мотивационная сфера личности носит смешанный характер: характерно ситуативное реагирование то с доминированием стремления избегать неудачи, то с мотивацией на успех.

Доминирующий тип направленности личности - направленность на дело. Данный тип направленности характеризуется заинтересованностью личности в решении деловых проблем, ориентацией на деловое сотрудничество. Главная цель для личности - достижение успеха в общем деле.

Ценностно-смысловая сфера личности характеризуется довольно высокими показателями по шкалам «процесс жизни», «результат жизни», «локус контроля жизнь». Такая личность оптимистично воспринимает свое прошлое, настоящее и будущее: прожитую часть жизни считает продуктивной, текущий процесс своей жизни - интересным и наполненным смыслом, будущее считает подконтрольным себе.

Конформистские ценности и ценности принятия других являются доминирующими, что может свидетельствовать о просоциальной личностной направленности, но неготовности занимать лидирующую позицию в обществе.

\section{Политик}

Мотивационная сфера личности носит смешанный характер: характерно ситуативное реагирование то с доминированием стремления избегать неудачи, то с мотивацией на успех.

Доминирующий тип направленности личности - направленность на дело. Личность характеризуется заинтересованностью в решении деловых проблем, способностью отстаивать в интересах дела собственное мнение, которое полезно для достижения общей цели.

Ценностно-смысловая срера личности характеризуется высокими показателями по шкалам «цели в жизни», «локус контроля - Я», «локус контроля - жизнь» и «осмысленность жизни». Данные результаты говорят о целеустремленности человека, представлении о себе как о сильной личности, обладающей достаточной свободой выбора, чтобы построить свою жизнь в соответствии со своими представлениями, способности контролировать свою жизнь, свободно принимать решения и воплощать их в реальность. Среди ценностей доминирующие позиции занимают индивидуалистические и ценности самоутверждения. Обе группы ценностей указывают на амбициозность личности, стремление к власти и достижениям. 


\section{Религиозный деятель}

Мотивационная сфера личности характеризуется доминированием мотивации на успех и высокими показателями мотивации достижения. Человек, начиная дело, при такой мотивации имеет в виду достижение чего-то конструктивного, положительного. В основе его активности лежит надежда на успех и потребность в достижении успеха. Такие люди обычно уверены в себе, в своих силах, ответственны, инициативны и активны. Их отличает настойчивость в достижении цели, целеустремленность.

У рассматриваемого типа личности доминируют два вида направленности: ориентация на общение и ориентация на дело. Совмещение этих видов направленности может говорить о стремлении личности поддерживать отношения с людьми, ориентации на совместную деятельность, деловое сотрудничество.

Ценностно-смысловая сфера личности характеризуется высокими показателями по всем шкалам, включая интегральный показатель осмысленности жизни. Доминирующими ценностями являются ценности принятия других и альтруистические ценности, что говорит о чрезвычайной важности добровольческой деятельности, помощи окружающим людям для данного типа личности. Человек для данного типа личности представляет собой наивысшую ценность.

\section{Автор проекта}

Мотивационная сфера личности характеризуется доминированием мотивации на успех и высокими показателями мотивации достижения. Человек, начиная дело при такой мотивации, имеет в виду достижение чего-то конструктивного, положительного. В основе его активности лежит надежда на успех и потребность в достижении успеха. Такие люди обычно уверены в себе, в своих силах, ответственны, инициативны и активны. Их отличает настойчивость в достижении цели, целеустремленность.

Доминирующий тип направленности - ориентация на общение. Для данного типа направленности характерно стремление при любых условиях поддерживать отношения с людьми, ориентация на совместную деятельность, потребность в привязанности и эмоциональных отношениях с людьми.

Ценностно-смысловая сфера личности характеризуется высокими показателями по всем шкалам, включая интегральный показатель осмысленности жизни. Доминирующими ценностями являются ценности принятия других и альтруистические ценности; значительно меньше, однако достаточно, чтобы считать характеристикой личности, выражены индивидуалистические ценности. Соответственно, можно предположить, что для данного типа личности характерна ориентация на окружающих людей, оказание им помощи и поддержки посредством личностного и профессионального развития.

Подводя итоги проведенного анализа результатов диагностики, можно резюмировать, что гипотетическое предположение о возможности выявления смысложизненных стратегий молодежи, различающейся по степени включенности в общественную деятельность, удалось реализовать на практике. Также были 
сформированы симптомокомплексы по каждому из выделенных типов личности, которые позволяют определить особенности молодежи и впоследствии разработать методы социально-психологической поддержки для каждого из типов организаций.

\section{Литература}

1. Brewis G., Russel J., Holdsworth C. Bursting the bubble - Students Volunteering and the Community. - URL: http://www.ivr.org.uk/evidence-bank/evidence-pages/ Bursting+the+Bubble-+Students+Volunteering+and+the+Community

2. Donahue K., Russell J. PROVIDE Volunteer Impact Assessment. - URL: http://www. ivr.org.uk/evidence-bank/evidence-pages/PROVIDE+Volunteer+Impact+Assess ment

3. Gaskin K. Young people volunteering and civic service. A review of literature. - URL: http://www.ivr.org.uk/evidence-bank/evidence-pages/Young+People+Volunteeri ng+and+Civic+Service.++A+Review+of+Literature

4. Holdsworth C. Student Volunteers. A national profile. - URL: http://www.ivr.org.uk/ evidence-bank/evidence-pages/Student+Volunteers.+A+National+Profile

5. Hustinx L. Individualization and a new styles of youth volunteering: an empirical exploration. - URL: http://www.ivr.org.uk/evidence-bank/evidence-pages/Individ ualisation+and+new+styles+of+youth+volunteering

6. Hutin M. Young people help out. - URL: http://www.ivr.org.uk/evidence-bank/ evidence-pages/Young+people+help+out

7. Tiger de Souza The role of higher education in the development of sports volunteers. URL: http://www.ivr.org.uk/evidence-bank/evidence-pages/The+role+of+higher+ education+in+the+development+of+sports+volunteers 